\title{
トピックス
}

\section{脊椎動物のサーカディアンリズムを 制御する遺伝子を探る}

\section{飯 郷 雅 之（聖マリアンナ医大・第一解剖）}

サーカディアンリズムは生物時計に支配さ れたリズムで, 環境の明暗など同調因子が存 在しない恒常環境下においてもおよそ24時間 の周期で継続する。これまでにホルモンを含 む様々な体内の機能がサーカディアンリズム を示すことが明らかになった。しかしながら， これまでに「なぜ生物時計は24時間の周期を 刻をことができるのか? 」といら根源の問題 については未だ解明されていない。

サーカディアンリズムを支配するサーカディ アンシステムの構成は, 生物時計への入力系, 生物時計そのもの, 出力系の 3 つに大別され る。生物時計そのものの機能を直接測定する ことは今のところ不可能なので, 生物時計に 関する研究は必然的に入力系, あるいは出力 系を报ったすのにならざるを得なかった。な かであ出力されてくる表現型りズムからのア プローチがこれまでに多くなされてきた。

一方, この半年ほどの間に発表された脊椎 動物のサーカディアンリズムに関する分子生 物学的研究の成果にはめざましいるのがある。 本稿では生物時計の実態解明を目指した $2 つ$ のアプローチを紹介する。

ショウショウパエやアカパンカビに批いて はサーカディアンリズムを支配する遗伝子と してそれぞれperiod, frequency が同定され， mRNAの転写調節がサーカディアンクロッ ク生成に重要な役割を果たしていることが明 らかになってきた。脊椎動物においても八ム スターにおいてサーカディアンリズムの周期 が短いtauミュータントが分離されてはいた が，サーカディアンクロックに関与する遗层 子の同定,クローニングはされていなかった。

アメリカのNSF Center for Biological Timing
のTakahashi らのグループは，マウスのサー カディアンリズムを支配する遣伝子を同定す るため, N-ethyl-N-nitrosourea といら変異 原を用いて突然変異誘発を行なった1)。彼ら はこれらのマウスの行動のサーカディアンリ ズム(出力系)を記録し，サーカディアンリズ 厶の 2 つの大きな特徵であるフリーランの周 期とリズムの安定性を指標にスクリーニング を行なった(1尾に 1 カ月以上かかる!)。そ して304尾の中から 1 尾のミュータントの分 離に成功した。正常なマウスは恒暗条件下て 24時間よりも短い周期(23.3-23.8時間)を示 すが，この個体は恒暗条件に移した後，徐々 に周期の延長を示し，30日後には24.8時間の 長い周期を示したのである。交配試験の結果， このミュータントは単一遗层子座の変異であ ることがわかり，Clock と命名された。さら にClockのホモ接合体 (Clock/ Clock)は恒暗 条件下でサーカディアンリズムをすぐに失っ てしまらことが判明した。さらに彼らは，47 種類の染色体マーカーを用いたlinkage analysisにより, Clockの染色体でのマッピング む行ない，第 5 染色体の上に存在することむ 明らかにした。残念ながらClock 遺伝子はま だクローニングされていないが，いずれクロー ニングされて，転写調節の解析が行なわれる ことたろう。ひょっとすると脊椎動物のサー カディアンリズム生成のメカニズムが解明さ れる日は近いのかもしれない。また，突然変

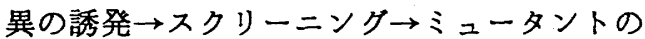
分離 $\rightarrow$ 染色体上のマッピング $\rightarrow$ クローニング $\rightarrow$ 転写調節の解析という流れで進んでいくで あろらこの研究の流れは他の研究にも応用し 得る普遍的なもので，今後多くの分野に応用 
されるものと思われる。

また一方では, サーカディアンリズムの同 調に関与する光受容器の側から生物時計に迫 ろうとするアプローチもなされている。松果 体ホルモンであるメラトニンはサーカディア ンリズムを示すホルモンのひとつである。ニ ワトリ,キンギョなど，いわゆる下等脊椎動 物の松果体細胞は, 光受容能(入力系)のみな らず生物時計機能とメラトニン合成系(出力 系)をあわせ持つ2)。この松果体に存在する 視物質のcDNAが最近日本のグループにより クローニングされ, pinopsin と名付けられ たのである(この研究グループは残念ながら 日本比較内分泌学会の会員ではなく, ライパ ル? の日本比較生理生化学会の会員である ${ }^{3)}$ 。 Pinopsin cDNAの塩基配列から予想されるア ミノ酸配列は，これまでに報告された網膜の 視物質 (ロドプシン, 赤, 緑, 青, 紫の錐体 オプシン) と $43 \sim 48 \%$ 相同で新たなグループ を構成することがわかった。Pinopsin mRNA の発現は松果体のみに認められ，また，培養 細胞において発現したpinopsinは470nmに 吸収極大を持つ青感受性の錐体型オプシンで あった。彼らは，このpinopsinのシグナル トランスダクション系を下流に向かってたど ることによって生物時計のメカニズム迫ろう としている。 サーカディアンリズムを研究する時間生物 学はまだ若い学問である。本稿においては脊 椎動物のサーカディアンリズムを制御する遺 伝子を探る 2 つのアプローチを紹介したが， この他にもメラトニン合成を制御する酵素serotonin N-acetyltransferase のcDNAクロー ニングや脳内光受容器の同定など解決しなけ ればならない問題は山積みされている。それ らの解決には大学や学部といった枠を越えた 学際的な協力体制を作り上げる必要があると 感じる今日この頃である。

\section{[参考文献]}

1) Vitaterna et al., (1994) Science 264, 719725 .

2 ) Takahashi et al. (1989) Rec Prog Horm Res 45, 279-352.

3) Okano et al. (1994) Nature 372, 94-97. 